\title{
Nitrogen Fertilization of Range: Yield, Pro- tein Content, and Cattle Behavior
}

\author{
M.J. SAMUEL, F. RAUZI, AND R.H. HART
}

\begin{abstract}
Effects of rate and season of nitrogen $(N)$ application on the utilization, crude protein, and yield of mixed prairie in southeastern Wyoming were evaluated. Fertilization increased herbage production, crude protein content and utilization by cattle as measured by both frequency of grazing and forage removal by grazing. Yield and protein content increased linearly with increased amounts of fall applied $N$, but non-linearly to spring applied $\mathbf{N}$. Forage removal showed a curvilinear response to both spring and fall applied $\mathbf{N}$ and was closely correlated with forage yield and frequency of grazing.
\end{abstract}

Much research on nitrogen $(\mathrm{N})$ fertilization of native rangeland has been conducted in recent years. Forage yields have been increased on native rangeland fertilized with $\mathrm{N}$ rates higher than $100 \mathrm{~kg} / \mathrm{ha}$ (Lorenz and Rogler 1972; Houston and Hyder 1975). Burzlaff et al. (1968) reported increased yield and crude protein content for rangeland fertilized at rates of 34 $\mathrm{kg} / \mathrm{ha}$ and higher but only higher protein content for forages fertilized at $17 \mathrm{~kg} / \mathrm{ha}$. Rauzi et al. (1968), using $\mathrm{N}$ rates of 37 and $74 \mathrm{~kg} / \mathrm{ha}$ reported inceased crude protein but no significant increase in forage yield at a site $19 \mathrm{~km}$ east of our study area. Most of the earlier range fertilization studies were conducted for 1 year or if for more than one year then either with spring or fall application.

Forage palatability usually is increased by $\mathrm{N}$ fertilization. Burton et al. (1956) applied from 0 to $1,681 \mathrm{~kg} \mathrm{~N} / \mathrm{ha}$ to coastal Bermudagrass (Cynodon dactylon). The percent of forage consumed by cattle increased with increasing $\mathrm{N}$ rate. They found no evidence to indicate that a rate as high as $1,681 \mathrm{~kg}$ $\mathrm{N} /$ ha reduced palatability. In three different studies, Cook (1965) applied $N$ at rates of 22 and 45, 34 and 67, or 45 and $90 \mathrm{~kg} / \mathrm{ha}$ to wheatgrass (Agropyron spp.) pastures. In each case, utilization increased in proportion to the amount of $\mathrm{N}$ applied. Nitrogen fertilization increased palatability of native species in Colorado (Hyder and Bement 1964).

Fertilization also can improve cattle distribution. Smith and Lang (1958) applied $75 \mathrm{~kg} \mathrm{~N} / \mathrm{ha}$ to a mountain range site. The utilization on this site was only $15 \%$ the year before fertilization. After fertilization, utilization was $73 \%$ in the treated area and $55 \%$ in the contiguous untreated area. Increased utilization

\footnotetext{
Authors are botanist, soil scientist, and agronomist, U.S. Department of Agriculture, Science and Education Administration, Agricultural Research. Samuel and Hart are with the High Plains Grasslands Research Station, Rt. 1 Box 698, Cheyenne, Wyo. 82001; Rauzi is with the Plant Sciences Division, P.O. Box 3354, University Station, Laramie, Wyo. 82071.

This work represents a cooperative investigation of the U.S. Dept. of Agriculture, SEA-AR and the Animal Science Division, University of Wyoming.

The authors thank K.V. Clark, V.M. Cook, F.A. Garland, R.C. Harmon, J.L. Shepherdson, and B.M. Weynand for their help with the study and the Biochemistry Division, University of Wyoming, for the crude protein analyses.

Manuscript received January 29, 1979.
}

from carry-over effects was significant the next year. Cook and Jefferies (1963) drifted cattle onto plots fertilized with $67 \mathrm{~kg}$ $\mathrm{N} / \mathrm{ha}$. When these animals revisted the area, they grazed the fertilized areas substantially more than the untreated areas. Hooper et al. (1969) measured the economic value of utilizing fertilized and adjacent unfertilized areas. They showed that, with proper planning and management, fertilization for improved livestock distribution may be profitable.

Our objective was to determine the effect of low rates of $\mathrm{N}$, applied annually either in the spring or fall, on herbage yield, protein content and use of mixed prairie vegetation by cattle.

\section{Study Area and Methods}

The High Plains Grasslands Research Station is located in southeastern Wyoming approximately $7 \mathrm{~km}$ west of Cheyenne. The topography is rolling hills of mixed grass prairie at an elevation of 1,890 to $1,950 \mathrm{~m}$. The $1941-1977$ average annual precipitation reported by the National Weather Service (U.S.D.C. 1941-1977) at the Cheyenne Airport was $365 \mathrm{~mm}$ with $70 \%$ occurring between April 1 and September 30. The soil on the experimental area is Archerson fine sandy loam, a member of the mixed, mesic family of Aridic Argiustolls. The range site was classed as loamy and consists of deep or moderately deep soils, well drained with a very fine sandy loam or silt loam surface layer. The top $1.2 \mathrm{~m}$ of the soil profile will hold $100-180 \mathrm{~mm}$ of available water (Rauzi et al. 1976). The vegetation of the experimental area consisted of $40 \%$ blue grama (Bouteloua gracilis), 20\% western wheatgrass (Agropyron smithii), $20 \%$ needleleaf sedge (Carex eleocharis), $10 \%$ other grasses, and $10 \%$ forbs by weight. Other grasses included needleandthread (Stipa comata), prairie junegrass (Koeleria cristata) and sandberg bluegrass (Poa secunda). The dominant forb was scarlet globemallow (Sphaeralcea coccinea).

The experimental design was a randomized block with five treatments and three replications. Nitrogen in the form of ammonium nitrate was applied annually at rates of 0,22 , and $34 \mathrm{~kg} \mathrm{~N} / \mathrm{ha}$ to $24 \times$ $30 \mathrm{~m}$ plots. Fertilizer was applied to one set of plots in late October of 1974, 1975, and 1976 for the fall treatment and late March of 1975, 1976, and 1977 for the spring treatment to another set of plots. In the spring of each year, five subplots of $0.18 \mathrm{~m}^{2}\left(1.92 \mathrm{ft}^{2}\right)$ in each main plot were randomly located and the previous year's vegetation was removed before plant growth started. Herbage in the subplots was clipped to ground level in August and separated by major species. Crude protein was determined (A.A.O.C., Kjeldahl) for the three major species, blue grama, western wheatgrass, and needleleaf sedge.

In early September yearling heifers were selected from the cow herd to graze all plots free choice. These animals were picked because of their distinctive color pattern, or if they were the same color they were painted differently to make them identifiable. The heifers were allowed 2 days to acquaint themselves with the 4-ha experimental area. Observations of grazing location were made by recording the plot in which each animal was actually grazing. These 
grazing events were recorded every 15 minutes for 3 to 4 hours during the morning and evening intensive grazing periods. In 1975, six heifers grazed for 11 days. In 1976 and 1977, five and six heifers, respectively, grazed for 14 days. Herbage subsamples for each main plot (two per plot in 1975, five per plot in 1976 and 1977) were clipped immediately after grazing.

\section{Results and Discussion}

Precipitation for the years $1974-1977$ was $251,272,279$, and $347 \mathrm{~mm}$, respectively, and was lower in all years than the 37-year average of $365 \mathrm{~mm}$ (U.S.D.C. 1941-1977). Herbage production was the same for all treatments in 1975 (Table 1). In 1976 herbage yields of all fertilized plots were significantly higher than those of the check. Spring applications of both rates and the $34 \mathrm{~kg} / \mathrm{ha}$ application in the fall produced higher herbage yields than did the check in 1977. Over 3 years, yield response to fall applied $\mathrm{N}$ was linear but response to spring applied $\mathbf{N}$ was non-linear (Table 1). Spring applied $\mathbf{N}$ gave higher yields than fall applied $\mathrm{N}$ at $22 \mathrm{~kg} / \mathrm{ha}$, but not at 34 $\mathrm{kg} / \mathrm{ha}$.

Table 1. Total herbage production ( $\mathrm{kg} / \mathrm{ha}$ ) of mixed prairie range under different rates of $\mathbf{N}$ fertilization $(\mathrm{kg} / \mathrm{ha})$.

\begin{tabular}{rccccc}
\hline \hline \multirow{N}{*}{$\begin{array}{l}\mathrm{N} \\
\text { rate }\end{array}$} & \multirow{2}{*}{$\begin{array}{l}\text { Season } \\
\text { applied }\end{array}$} & 1975 & 1976 & 1977 & Mean \\
\cline { 3 - 6 } & - & $781 \mathrm{a}^{1}$ & $760 \mathrm{~b}$ & $761 \mathrm{c}$ & 769 \\
\hline 0 & Spring & $872 \mathrm{a}$ & $1207 \mathrm{a}$ & $1171 \mathrm{a}$ & $1083 \mathrm{a}$ \\
22 & Fall & $853 \mathrm{a}$ & $1050 \mathrm{a}$ & $909 \mathrm{bc}$ & 937 \\
22 & Spring & $984 \mathrm{a}$ & $1178 \mathrm{a}$ & $1029 \mathrm{ab}$ & 1064 \\
34 & Fall & $937 \mathrm{a}$ & $1178 \mathrm{a}$ & $1039 \mathrm{ab}$ & 1051 \\
34 & &
\end{tabular}

' In this and the next tables, means in the same column followed by the same letter are not significantly different at the 5\% level according to Duncan's multiple range test.

Application of $22 \mathrm{~kg} \mathrm{~N} / \mathrm{ha}$ in spring significantly increased crude protein content of all three major species in all years (Table 2). Responses to fall applied $\mathrm{N}$ or to $34 \mathrm{~kg} / \mathrm{ha}$ spring applied $\mathrm{N}$ were smaller. The crude protein content of all three species responded in a similar manner, as shown by high inter-species correlations of the 3-year means $\left(r^{2}\right.$-values were as follows: western wheatgrass vs. blue grama, .81; western wheatgrass vs. needleleaf sedge, .96; blue grama vs. needleleaf sedge, .93). Mean crude protein content of three species followed a pattern similar to that of forage yield, with a linear response to fall applied $\mathrm{N}$ and a non-linear response to spring applied $\mathrm{N}$, with no differences between season of application at a rate of $34 \mathrm{~kg} \mathrm{~N} / \mathrm{ha}$.

In all 3 years, plots fertilized in the spring with $22 \mathrm{~kg} \mathrm{~N} / \mathrm{ha}$ were grazed more often than were the check plots (Table 3 ). The plots receiving $22 \mathrm{~kg} \mathrm{~N} / \mathrm{ha}$ in the fall and either spring or fall applications of $34 \mathrm{~kg} \mathrm{~N} / \mathrm{ha}$ were grazed significantly more often then were the checks for 2 of the 3 years. All fertilized
Table 3. Frequency of grazing and forage removal by grazing on mixed prairie range under different rates of $\mathbf{N}$ fertilization.

\begin{tabular}{|c|c|c|c|c|c|c|c|}
\hline $\begin{array}{l}\text { N rate } \\
(\mathrm{kg} / \mathrm{ha})\end{array}$ & $\begin{array}{l}\text { Season } \\
\text { applied }\end{array}$ & 1975 & 1976 & 1977 & 1975 & 1976 & 1977 \\
\hline & & \multicolumn{6}{|c|}{ Frequency of grazing } \\
\hline & & \multicolumn{3}{|c|}{ Events/plot, \% of total } & \multicolumn{3}{|c|}{$\begin{array}{l}\text { Relative number } \\
\text { events/t forage }\end{array}$} \\
\hline 0 & - & $3.0 \mathrm{~b}$ & $3.7 \mathrm{~b}$ & $3.0 \mathrm{~b}$ & $3.8 \mathrm{~b}$ & $4.9 \mathrm{~b}$ & $3.9 \mathrm{~b}$ \\
\hline 22 & Spring & $8.7 \mathrm{a}$ & $8.6 \mathrm{a}$ & $8.7 \mathrm{a}$ & $10.0 \mathrm{a}$ & $7.1 \mathrm{a}$ & $7.4 \mathrm{a}$ \\
\hline 22 & Fall & $7.5 \mathrm{a}$ & $5.3 \mathrm{ab}$ & $6.9 \mathrm{a}$ & $8.8 \mathrm{a}$ & $5.1 \mathrm{~b}$ & $7.6 \mathrm{a}$ \\
\hline 34 & Spring & $9.4 \mathrm{a}$ & $6.8 \mathrm{ab}$ & $7.2 \mathrm{a}$ & $9.6 \mathrm{a}$ & $5.8 \mathrm{ab}$ & $7.0 \mathrm{a}$ \\
\hline \multirow[t]{3}{*}{34} & Fall & $6.4 \mathrm{ab}$ & $8.9 \mathrm{a}$ & $7.6 \mathrm{a}$ & $6.8 \mathrm{ab}$ & $7.6 \mathrm{a}$ & $7.3 \mathrm{a}$ \\
\hline & & \multicolumn{6}{|c|}{ Removal by grazing } \\
\hline & & \multicolumn{3}{|c|}{$\mathrm{kg} / \mathrm{ha}$} & \multicolumn{3}{|c|}{$\%$} \\
\hline 0 & - & $53 \mathrm{a}$ & $-13 b$ & $-21 b$ & $3 a$ & $-2 b$ & $-3 b$ \\
\hline 22 & Spring & $117 \mathrm{a}$ & $435 \mathrm{a}$ & $237 a b$ & $15 \mathrm{a}$ & $39 a$ & $21 \mathrm{a}$ \\
\hline 22 & Fall & $260 \mathrm{a}$ & $278 \mathrm{ab}$ & $116 \mathrm{ab}$ & $33 a$ & $29 a$ & $14 \mathrm{ab}$ \\
\hline 34 & Spring & $360 a$ & 432 a & $208 a b$ & $41 \mathrm{a}$ & $39 a$ & $22 \mathrm{a}$ \\
\hline 34 & Fall & $201 \mathrm{a}$ & $305 \mathrm{a}$ & 297 a & $23 a$ & $29 \mathrm{a}$ & $28 \mathrm{a}$ \\
\hline
\end{tabular}

plots were grazed significantly more often than was the check in 1977. Because it was possible that cattle might have spent more time grazing in plots with more herbage, grazing events also were expressed as the relative frequency of grazing per metric ton of herbage dry matter (events per plot/herbage yield $\times 1,000)$. However, grazing frequency per herbage unit followed the same pattern as grazing events per plot. Both showed a non-linear response to $\mathrm{N}$ rate, with more grazing on spring fertilized than on fall fertilized plots at $22 \mathrm{~kg} / \mathrm{ha}$, but not at $34 \mathrm{~kg} / \mathrm{ha}$.

Although a much higher percentage of forage was removed by grazing from fertilized than from unfertilized plots in 1975 (Table 3), the differences were not significant. In 1975 only two subsamples per main plot were clipped after grazing; this small sample produced high variation within treatments that probably accounted for the lack of significance. Five subsamples on each main plot were clipped in 1976 and 1977 both before and after grazing; and the percentage of forage removed from the fertilized treatments was measurably higher than from the check, except from plots receiving $22 \mathrm{~kg} / \mathrm{ha}$ in the fall in 1977. Forage removal expressed as percent of production followed a non-linear response to $\mathrm{N}$ at both application dates. Percent removal from fall fertilized plots appeared to reach a maximum at a lower $\mathbf{N}$ rate and to decline more rapidly thereafter than percent removal from spring fertilized plots. However, when removal was expressed in $\mathrm{kg} / \mathrm{ha}$, the amount of forage removed increased rapidly from 0 to $22 \mathrm{~kg} \mathrm{~N} / \mathrm{ha}$, then showed little increase to $34 \mathrm{~kg} \mathrm{~N} / \mathrm{ha}$. Removal from spring fertilized range was somewhat higher than that from fall fertilized range. The percentage of the total forage removed by grazing was closely correlated with relative grazing frequency per unit of forage $\left(r^{2}=.97\right)$. The weight of

Table 2. Crude protein content (\%) of major species of mixed prairie range under different rates of $\mathrm{N}$ fertilization (kg/ha).

\begin{tabular}{|c|c|c|c|c|c|c|c|c|c|c|}
\hline \multirow{2}{*}{$\begin{array}{l}\mathrm{N} \\
\text { rate }\end{array}$} & \multirow{2}{*}{$\begin{array}{l}\text { Season } \\
\text { applied }\end{array}$} & \multicolumn{3}{|c|}{ Westem wheatgrass } & \multicolumn{3}{|c|}{ Blue grama } & \multicolumn{3}{|c|}{ Needleleaf sedge } \\
\hline & & 1975 & 1976 & 1977 & 1975 & 1976 & 1977 & 1975 & 1976 & 1977 \\
\hline $\begin{array}{r}0 \\
22 \\
22 \\
34 \\
34\end{array}$ & \begin{tabular}{l}
\multicolumn{1}{c}{-} \\
Spring \\
Fall \\
Spring \\
Fall
\end{tabular} & $\begin{array}{r}7.5 \mathrm{~b} \\
10.5 \mathrm{a} \\
9.4 \mathrm{ab} \\
9.6 \mathrm{ab} \\
9.5 \mathrm{ab}\end{array}$ & $\begin{array}{l}12.0 \mathrm{~b} \\
15.5 \mathrm{a} \\
13.3 \mathrm{ab} \\
13.7 \mathrm{ab} \\
14.1 \mathrm{ab}\end{array}$ & $\begin{array}{l}11.8 \mathrm{~b} \\
14.4 \mathrm{a} \\
12.4 \mathrm{ab} \\
13.8 \mathrm{ab} \\
14.2 \mathrm{a}\end{array}$ & $\begin{array}{l}9.1 \mathrm{~b} \\
12.5 \mathrm{a} \\
11.3 \mathrm{ab} \\
12.6 \mathrm{a} \\
11.8 \mathrm{ab}\end{array}$ & $\begin{array}{l}10.9 \mathrm{~b} \\
13.6 \mathrm{a} \\
14.0 \mathrm{a} \\
13.8 \mathrm{a} \\
14.1 \mathrm{a}\end{array}$ & $\begin{array}{r}9.8 \mathrm{~b} \\
11.7 \mathrm{a} \\
10.5 \mathrm{~b} \\
11.9 \mathrm{a} \\
11.9 \mathrm{a}\end{array}$ & $\begin{array}{c}9.7 \mathrm{~b} \\
12.9 \mathrm{a} \\
11.5 \mathrm{ab} \\
12.8 \mathrm{a} \\
12.5 \mathrm{a}\end{array}$ & $\begin{array}{l}12.9 \mathrm{~b} \\
16.4 \mathrm{a} \\
15.0 \mathrm{a} \\
15.1 \mathrm{a} \\
15.7 \mathrm{a}\end{array}$ & $\begin{array}{l}11.4 \mathrm{c} \\
13.7 \mathrm{a} \\
12.2 \mathrm{bc} \\
13.1 \mathrm{ab} \\
13.6 \mathrm{a}\end{array}$ \\
\hline
\end{tabular}


forage removed was more closely correlated with forage yield $\left(r^{2}=.90\right)$ than with grazing frequency. For the grazing period and type of cattle use in this study, approximately one additional kilogram of forage was grazed for each additional kilogram of forage produced.

Maturity of forage plants can be a factor in determining palatability and degree of utilization by cattle (Marten 1970). However, maturity was unimportant in this study because herbage on all treatments had reached an equally advanced stage of maturity by the time the experimental area was grazed.

\section{Conclusions}

Nitrogen fertilization of mixed-grass prairie increased the herbage production; the crude protein content of western wheatgrass, blue grama, and needleleaf sedge; and the utilization of forage by grazing heifers. Spring $\mathbf{N}$ application produced higher yields, crude protein content, and grazing frequency than fall $\mathrm{N}$ application at $22 \mathrm{~kg} / \mathrm{ha}$ but not at 34 $\mathrm{kg} / \mathrm{ha}$. Application of $34 \mathrm{~kg} / \mathrm{ha}$ at either season did not result in greater yield, protein content, or utilization than did application of $22 \mathrm{~kg} / \mathrm{ha}$ in the spring. Because years of belownormal precipitation are certain to occur, although not predictably, our study during a 4-year period of low precipitation showed that the conservative treatment of $22 \mathrm{~kg}$ $\mathrm{N} /$ ha applied in the spring would be most consistently effective.

Cattle clearly preferred to graze $\mathrm{N}$-fertilized range over unfertilized range when the two were contiguous. If this preference is strong enough, cattle might move considerable distances to graze fertilized range. Thus, fertilization to attract cattle to previously underutilized range should be studied further.

\section{Literature Cited}

Burton, G.W., B.L. Southwell, and J.C. Johnson, Jr. 1956. The palatability of coastal bermudagrass (Cynodon dactylon (L.) Pers.) as influenced by nitrogen level and age. Agron. J. 48:360-365.

Burzlaff, D.F., G.W. Fick, and L.R. Rittenhouse. 1968. Effect of nitrogen fertilization on certain factors of a western Nebraska range ecosystem. J. Range Manage. 21:21-24.

Cook, C.W. 1965. Plant and livestock responses to fertilized rangelands. Utah Agr. Exp. Sta. Bull. 455. 35 p.

Cook, C.W., and N. Jefferies. 1963. Better distribution of cattle on mountain ranges. Utah Sci. 24:31, 48-49.

Hooper, J.F., J.P. Workman, J.B. Grumbles, and C.W. Cook. 1969. Improved livestock distribution with fertilizer-a preliminary economic evaluation. J. Range Manage. 22:108-110.

Houston, W.R., and D.N. Hyder. 1975. Ecological effects and fate of $\mathrm{N}$ following massive $\mathrm{N}$ fertilization of mixed-grass plains. J. Range Manage. 28:56-60.

Hyder, D.N., and R.E. Bement. 1964. Six weeks fescue as a deterrent to blue grama utilization. J. Range Manage. 17:261-264.

Lorenz, R.J., and G.A. Rogler. 1972. Forage production and botanical composition of mixed prairie as influenced by nitrogen and phosphorus fertilization. Agron. J. 64:244-249.

Marten, G.C. 1970. Measurement and significance of palatability. In: Proc. of National Conference on Forage Quality Evaluation and Utilization. D1-D55. Nebraska Center for Continuing Education, Lincoln.

Rauzi, F., R.L. Lang, and L.I. Painter. 1968. Effects of nitrogen fertilization on native rangeland. J. Range Manage. 21:287-291.

Rauzi, F., A. Stevenson, and C. McAfee. 1976. A preliminary report on range sites and condition for two native pastures at the High Plains Grasslands Research Station Cheyenne Wyoming. Wyo. Agr. Exp. Sta. Res. J. 103. $23 \mathrm{p}$.

Smith, D.R., and R.L. Lang. 1958. The effect of nitrogenous fertilizers on cattle distribution on mountain range. J. Range Manage. 11:248-249.

U.S. Dep. of Commerce. National Oceanic and Atmospheric Administration. 1941-77. Local Climatological Data. Cheyenne, Wyo.

CHANGE OF ADDRESS notices should be sent to the Managing Editor, 2760 West Fifth Ave., Denver, Colo. 80204, no later than the first day of the month of issue. Copies lost due to change of address cannot be replaced unless adequate notice is given. To assure uninterrupted service, provide your local postmaster with a Change of Address Order (POD Form 3575) indicating thereon to guarantee forwarding postage for second-class mail. 